\title{
A objetividade no fotojornalismo: do testemunho ao traço do real
}

\author{
THE OBJECTIVITY IN PHOTOJOURNALISM: \\ FROM TESTIMONY TO TRACE OF THE REAL
}

\section{Renata Lohmann}

Bacharel em Comunicação Social - Jornalismo, Mestre em Comunicação e Informação, com ênfase em Cultura e Significação, doutoranda em Comunicação e Informação pela Universidade Federal do Rio Grande do Sul. Integrante do Grupo de Estudos sobre Comunicação e Imaginário (Imaginalis). E-mail: relohmann@gmail.com

\section{Ana Taís Martins Portanova Barros}

Bacharel em Comunicação Social - Jornalismo pela Universidade Federal do Rio Grande do Sul. Mestre e Doutora em Ciências da Comunicação pela Universidade de São Paulo. Professora do programa de pós-graduação em Comunicação e Informação e da graduação em Comunicação Social na Universidade Federal do Rio Grande do Sul. Fundadora e coordenadora do Grupo de Estudos sobre Comunicação e Imaginário (Imaginalis).

E-mail: anataismartins@icloud.com

Recebido em 23 de janeiro de 2018. Aprovado em 25 de abril de 2018.

\section{Resumo}

Este artigo tem como objetivo estudar a questão da objetividade no fotojornalismo. Para tal, faz um estudo do que é o fotojornalismo, sua história e seus conceitos formadores. Apresenta também a evolução dos paradigmas que conceituam a fotografia e o fotojornalismo, desde seu surgimento, e como a crença na objetividade, tão marcada nos primórdios, foi sendo reavaliada pelo homem.

Palavras-chave: Fotojornalismo. Objetividade. Fotografia. Real.

\section{Abstract}

This article aims to study the issue of objectivity in photojournalism. To do so, it researches what is photojournalism, its history and primary concepts. This article also shows the evolution of the paradigms that conceptualize photography and photojournalism since its beginning and how the belief in objectivity, so striking in the early days, has been reassessed by man.

Keywords: Photojournalism. Objectivity. Photography. Real. 


\section{Introdução}

A objetividade foi, durante muito tempo, característica notável da fotografia como forma de representação, e por consequência, do fotojornalismo. Durante os séculos 19 e 20, acompanhamos extraordinárias mudanças nas formas de comunicação, com o surgimento do cinema, da televisão e da internet. Com essas mudanças tecnológicas, vemos o homem questionando seu papel no mundo e as formas de representação que utiliza para se comunicar.

A objetividade intrínseca ao aparelho fotográfico passa a ser questionada, assim como as implicações filosóficas e éticas para o fotojornalismo: como mostrar a verdade se o aparelho é operado por um indivíduo que possui pontos de vista, opiniões, e que realiza escolhas ao registrar a imagem?

Já em seus primórdios, a fotografia abala a sociedade, as artes e a forma do homem ver o mundo e a si mesmo. Num universo onde as representações só eram possíveis através de técnicas que dependiam de um artista, a viabilidade de um aparato produzir essa imagem automaticamente era incrivelmente sedutora. Eis que surge um dos primeiros fatores cruciais para a classificação e compreensão da fotografia no século 19, e por quase todo o século 20: ela era diferente da arte. O embate da arte contra a fotografia era evidente; Daguerre, que desenvolve o daguerreótipo, é apoiado pela Academia das Ciências; Bayard, que faz fotografias diretamente sobre papel, pela Academia de Belas Artes (ROUILLÉ, 2009). Já naquele momento, não é vislumbrada uma possível conciliação entre arte e fotografia.

Por parte do mundo da arte, a fotografia é vista como uma ferramenta prática e útil, mas que, justamente por não possuir a influência da mão humana, como a pintura, não é considerada arte. Entre outros fatores, se encontra o de a fotografia não hierarquizar nenhum objeto dentro da imagem, como um pintor poderia fazer em sua pintura. Segundo Rouillé (Ibid., p. 74), para os artistas, pintura e fotografia não eram compatíveis, já que na pintura existe uma semelhança interior espiritual, uma interpretação, dignas da arte, enquanto na fotografia, existe um status de simulacro, uma cópia cuja semelhança se dá no caráter externo, portanto, incompatível com a arte.

A fotografia também é colocada fora do campo da arte pela sua possibilidade de reprodução. Enquanto um quadro é considerado uma obra por ser uma peça única e original, a fotografia possibilita infinitas cópias, o que causa mais uma tensão entre as duas áreas.

Um quadro tradicional é um original: único e não multiplicável. [...] São os objetos que têm valor enquanto objetos. [...] A fotografia, por sua vez, é multiplicável. Distribuí-la é multiplicá-la. [...] Enquanto objeto, seu valor é desprezível. É o primeiro objeto pós-industrial; o valor se transferiu do objeto para a informação. (FLUSSER, 2002, p. 44) 
A fotografia ganha, já em seu princípio, a qualidade da objetividade. Bazin (apud DUBOIS, 1993, p. 34) diz que a originalidade da fotografia em contraposição à pintura reside nessa objetividade que resulta da formação automática da imagem, sem a interferência criadora do homem.

O caráter de testemunha da fotografia é contíguo ao de objetividade. Já que a imagem se parece com o real, como vista de uma janela, e é feita por um aparelho que funciona automaticamente, certamente serve como uma testemunha dos acontecimentos. Sua função, assim que começou a ser utilizada nos veículos impressos, era justamente essa: não precisava dar informações adicionais à notícia, apenas servir de testemunha para o que era relatado, dar credibilidade às informações do jornal. Utilizar a fotografia nos veículos impressos também foi uma inovação incrível: a partir desse momento, as pessoas poderiam ver acontecimentos e lugares sem precisar sair de suas casas. Por mais que as gravuras já tivessem essa função, a fotografia era muito mais precisa. Tanto foi um aperfeiçoamento e um diferencial que os jornais faziam questão de deixar evidentes até os dados técnicos de como a foto foi capturada, escrevendo nas legendas informações como tempo de exposição, distância do objeto e condições do ambiente (LOUZADA, 2008).

Segundo Flusser (2002, p. 14), a objetividade das imagens técnicas é ilusória, aparente, pois elas são tão simbólicas quanto qualquer outra imagem. Bourdieu (apud DUBOIS, 1993, p. 40) reafirma isso ao falar sobre os usos sociais da fotografia, que só é considerada absolutamente realista, como um espelho da realidade, como uma testemunha dos acontecimentos, porque assim lhe foi designado desde seu surgimento. A própria hostilidade com que a arte tratou essa recém-nascida forma de representação levou a esse caminho. De acordo com Dubois (Ibid.), o poeta Baudelaire era um grande discriminador da fotografia e da arte, legando à fotografia o papel de memória documental do real, considerando a arte como pura criação imaginária. Tamanho foi o impacto da fotografia na vida do homem moderno que esse não soube muito bem o que fazer com ela. Restou para a fotografia o papel que lhe impuseram desde sua criação, do espelho da realidade, e aos fotógrafos e pensadores visionários, a função de questionar o papel legado a essa surpreendente e instigante forma de representação.

\section{O que é fotojornalismo: história e conceitos formadores}

O fotojornalismo surge a partir do momento em que a fotografia é desenvolvida como mecanismo de reprodução da realidade visual. As fotografias passam a ser utilizadas, a partir de meados do século 19, nas primeiras publicações ilustradas europeias, para transmitir informações úteis (de valor jornalístico) conjugando imagem e texto 
(SOUSA, 2000). Sua finalidade primordial é informar. Essas imagens ainda não eram consideradas fotojornalismo propriamente dito, já que ainda necessitavam do intermédio de desenhistas para serem publicadas nos periódicos. Nessa época, segundo Sousa (Ibid., p. 25), não eram raras as manipulações feitas pelos gravuristas enquanto elaboravam suas ilustrações a partir de originais fotográficos. Ainda assim, tinham a ambiciosa missão de dar testemunho do que presenciavam ao leitor, graças ao seu atribuído caráter de "realismo". O surgimento da impressão direta é fundamental, já que, sem o auxílio de desenhistas, consegue-se atestar a fotografia como forma de representação que se sustenta sozinha, sem a interferência da mão humana, a não ser para disparar a foto. Segundo Sousa (Ibid., p. 44), a base tecnológica para a impressão direta surge em 1880, com a técnica do halftone. Por ser uma técnica de impressão cara e por contrariar o gosto estético vigente do público, a introdução e popularização do halftone demorou a se concretizar, e os gravuristas continuaram tendo um papel de destaque na produção de imagens por anos.

Tecnologias como a do colódio úmido, substituindo o daguerreótipo, possibilitaram grandes mudanças nos níveis culturais, de rotinas e convenções, já que a partir desse momento, atinge-se maior grau de movimentação com os pesados equipamentos. Esse caráter de instantaneidade e movimentação reitera a crença de que o que era fotografado era verdadeiro - verdade como "o plano da imanência traçado pela fotografia, onde o Real substitui o Ideal transcendente, é o território do verdadeiro fotográfico" (ROUILLÉ, 2009, p. 60). A ação do objeto passa a ser "congelada" instantaneamente: logo, a imagem não mentiria. Além disso, a tecnologia do colódio úmido e seu processamento negativo-positivo possibilitam a infinita reprodução das imagens, distanciando, já em princípio, a fotografia das artes. Apesar de permitir maior flexibilidade na movimentação do fotógrafo, a utilização do colódio úmido gera outros problemas, já que a foto precisava ser feita com a emulsão úmida sobre a chapa, e revelada antes de secar. Isso trazia a necessidade de um laboratório móvel: o fotógrafo continuava, de alguma forma, preso ao seu pesado equipamento.

A história da fotografia, seu desenvolvimento técnico e a evolução da relação humana com a imagem estão intimamente ligados com as guerras e conflitos dos séculos 19 e 20, bem como uma mudança nos valores e ideais do homem e sua forma de ver a fotografia e a si mesmo.

A guerra é um tema sedutor para as pessoas - já era tema dos grandes pintores. A fotografia tem a missão de mostrar a guerra por dentro, direto dos campos de batalha, sangue e suor diretamente para o conforto do lar do leitor. A Guerra da Crimeia (1853-1856) foi a primeira registrada pela câmera fotográfica de Roger Fenton, e publicada através de gravuras. Fenton passa a ser considerado o primeiro repórter fotográfico (SOUSA, 2000). 
Porém, devido à tecnologia arcaica e à censura do próprio fotógrafo, Fenton não se aproxima muito dos campos de batalha, e sua visão da guerra é limpa, sem imagens que mostrem o sangue, os horrores e as perdas humanas.

Com limitações técnicas semelhantes às de Fenton, Mathew Brady fotografa a Guerra da Secessão Americana (1861-1865). Nessa cobertura, percebeu-se o poder de persuasão e carga dramática que a fotografia possuía em detrimento da pintura, devido a seu caráter de realismo e verossimilhança. Para tanto, era preciso estar próximo dos acontecimentos. Para vencer a concorrência, era preciso ser veloz, trazer as imagens em primeira mão. Pela primeira vez, os fotógrafos arriscam suas vidas estando mais próximos das batalhas.

Outro fator técnico importante para o caráter imediato da fotografia são as emulsões mais sensíveis à luz e equipamentos menores. Em 1884, George Eastman e W. Walker desenvolvem a primeira película fotográfica em tira, que era muito mais leve e manipulável que as chapas de vidro ou metal. Em 1888 Eastman inventa a primeira câmera Kodak, promovendo o uso massivo e democrático da câmera fotográfica. Com o slogan "Você aperta o botão. Nós fazemos o resto", qualquer um é capaz de fotografar; os complexos e pesados aparelhos fotográficos não são mais necessários - ao menos para o fotógrafo amador -, assim como conhecimentos de laboratório fotográfico.

No Brasil, é possível perceber que as tendências técnicas se desenvolvem da mesma forma que na Europa e nos Estados Unidos, porém, com um pequeno atraso. $\mathrm{O}$ primeiro periódico ilustrado com fotografias a ser publicado no Brasil é a Revista da Semana, publicada em 1900. Em 1908 é criada a revista Careta, e em 1914, a Fon-Fon. Essas eram publicações tradicionais que acabaram por se adaptar ao novo padrão de associação texto-imagem (MAUAD, 2004). Em 1928, a revista O Cruzeiro é lançada e se torna um marco na história das publicações ilustradas brasileiras. Ela assume os modelos internacionais de revistas, como a Life, e com isso impulsiona as outras publicações a se adequarem a um padrão de qualidade fotográfica maior. Tinha em seus princípios básicos o papel do fotógrafo como testemunha ocular e a ideia de que a fotografia podia elaborar uma narrativa linear dos fatos. Mauad credita a David Nasser e Jean Manzon o título de primeiros fotojornalistas brasileiros. As revistas ilustradas brasileiras utilizavam a disposição de sequências de fotos na sua ordem cronológica, para dar ao leitor a sensação de ser uma testemunha dos fatos. Essas sequências formavam uma narração visual e espacial do ocorrido (LOUZADA, 2008).

Já nos jornais diários, o Correio da Manhã, de 1901, começa a publicar fotografias a partir de 1902; o Jornal do Brasil, de 1891, a partir de 1905 e o Gazeta de Notícias, de 1875, a partir de 1907. A Gazeta de Notícias também é o primeiro jornal a imprimir 
fotografias colorizadas, depois de modernizar seu parque gráfico. Entre 1920 e 1930, as fotografias de outros países chegavam ao Brasil de avião. Nesse período, o telégrafo era utilizado para a transmissão de informações e um sistema de igual velocidade se fazia necessário para as imagens. Em 1936, o jornal O Globo moderniza seus sistemas de transmissão, e recebe e publica a primeira radiofoto, fotografia que foi enviada da Europa para o Brasil por meio de ondas de rádio. Esse sistema posteriormente evoluiu para a telefoto, cuja transmissão é realizada via telefone. Em 1950, o ideal da fotorreportagem no Brasil chega à sua maturidade com a revista O Cruzeiro, e em 1951, com o jornal Última Hora, se chega ao ideal de que uma boa foto de capa é garantia de sucesso de vendas.

$\mathrm{O}$ automatismo do processo engendra a tese da gênese fotográfica, que crê ser a foto um atestado de existência do que mostra. Segundo Sousa (2000, p. 33), "a foto beneficiava também das noções de 'prova', 'testemunho' e 'verdade', que à época lhes estavam profundamente associadas e que a davam crédito como 'espelho do real"'.

Para Dubois (1993, p. 26), nesse primeiro momento, a fotografia é definida como espelho do real. Ela seria a imitação mais perfeita possível da realidade devido à semelhança, à capacidade de mimetismo com os objetos reais. Nessa definição, a gênese automática (BAZIN apud DUBOIS, 1993, p. 35) é um dos fatores fundamentais para sua fidelidade com a realidade. A fotografia liberta a pintura e as gravuras do seu papel de representação realista. Bazin, porém, é um dos primeiros a deslocar a questão do realismo, mesmo que de forma sutil. Ele insiste na naturalidade e objetividade da imagem fotográfica, mas diferentemente das ideias vigentes, diz que a semelhança entre imagem e objeto não é produzida necessariamente pela sua gênese automática. Ele não está negando o valor mimético da fotografia, mas sim dizendo que é um mero resultado. $\mathrm{O}$ fazer fotográfico é muito mais importante do que a imagem:

A ontologia da foto está, em primeiro lugar, nisso. Não no efeito do mimetismo, mas na relação de contiguidade momentânea entre a imagem e seu referente, no princípio de uma transferência das aparências do real para a película sensível. (DUBOIS, 1993, p. 35)

O realismo não está sendo negado, mas deslocado. O caráter testemunhal da fotografia vem de sua objetividade, pois há uma credibilidade na fotografia que inexiste nas pinturas. Nos vemos obrigados a acreditar na existência do objeto representado, porque a fotografia o posiciona como presente no tempo e no espaço. É transferência de realidade do objeto para a imagem (BAZIN apud DUBOIS, 1993, p. 35). Seu peso vem do fato de ela ser um traço do real, e não de sua semelhança com o real. Essa gênese automática (BAZIN apud DUBOIS, 1993, p. 35), torna a fotografia uma testemunha; somos levados 
a acreditar na existência do objeto fotografado. Porém, por mais que a imagem seja uma testemunha do referente, isso não significa que ela se pareça com ele. Ela atesta a existência física do objeto, mas não lhe dá sentido. Logo, seu peso real vem do fato de ela ser um traço do real, e não de sua semelhança com o real (DUBOIS, 1993, p. 35).

Com esses novos conceitos, a fotografia gradualmente começa a ser definida como transformação do real (Ibid., 1993). A fotografia passa a ser agora código e desconstrução. A ideia de transformação do real é dominante no século 20 e foi fortemente influenciada pelo estruturalismo como um movimento de crítica e denúncia da impressão de realidade das fotografias. Essa transição de definições ocorre juntamente com o que Sousa (2000) considera a primeira revolução no fotojornalismo. Um dos fatores históricos importantes para essa revolução foi a Primeira Guerra Mundial. Nela, pela primeira vez, há um fluxo constante de fotografias. Isso mostra que já começam a se traçar os rumos da massificação da produção fotojornalística. A maioria das fotografias era de planos gerais e havia um esforço por parte dos fotógrafos para mostrar uma guerra limpa. A Guerra Civil Espanhola foi a primeira a ser amplamente fotografada e serviu como ensaio para as seguintes. Nela, a maioria dos fotógrafos escolheu uma posição, um lado para apoiar, atitude que antes era mascarada, escondida. Começa a se pensar em pontos de vista nesse momento. É a partir da década de 1950, na Guerra da Coreia, que se começam a mostrar abertamente os horrores da guerra.

Nessa primeira revolução, há uma ruptura das fronteiras temáticas do fotojornalismo, um maior desenvolvimento da fotorreportagem. A evolução da estética cada vez mais faz confundir fotografia com arte e expressão (Ibid.). Nesse mesmo período, a fotomontagem começa a ser utilizada em temas de política, de forma a causar polêmica, especialmente na época da Alemanha nazista. A candid photography ${ }^{1}$, fotografia não protocolar, começa a se tornar cada vez mais recorrente. Essas mudanças de visão e de valores começam a encaminhar o fotojornalismo para uma ideia de fotografia codificada, sob os aspectos culturais, técnicos, sociológicos e estéticos. Essa codificação desloca a noção de realismo de sua fixação empírica para o que se chama de princípio de uma verdade interior. Funções diferentes começam a ser vislumbradas para o fotojornalismo, e isso faz com que as suas técnicas de produção sejam repensadas.

Com as teorias da representação, de Rudolf Arnheim, começa a se falar sobre as diferenças aparentes que a fotografia apresenta em relação ao real. A imagem é

1 Candid photography é um estilo de fotografia focado na espontaneidade, em detrimento da técnica apurada. Em contraste com a fotografia tradicional, a candid photography não é posada ou planejada; é instantânea e o fotógrafo está imerso dentro do ambiente sem ser intrusivo. Não há nenhum tipo de "perseguição" ou "tocaia"; nela o fotógrafo está dentro do ambiente com os "sujeitos” fotografados, próximo, porém não escondido. 
determinada por ângulo de visão, distância do objeto e enquadramento específicos, pela redução da tridimensionalidade para a bidimensionalidade, pela transformação das variações cromáticas em gamas de preto e branco. $\mathrm{O}$ isolamento preciso do tempo e do espaço é puramente de caráter visual. Aqui, de novo podemos perceber a conclusão de Bourdieu (apud DUBOIS, 1993, p. 40), que diz que a fotografia é considerada um registro objetivo porque assim the foi designado desde sua criação. Analisando antropologicamente a fotografia, chega-se à conclusão de que as significações das fotografias são determinadas culturalmente, que elas não são evidentes para todos os receptores e que códigos de leitura se fazem necessários para compreendê-la. A partir da percepção dessa codificação, a fotografia deixa de ser vista como representação transparente, inocente e realista em sua essência. Esse é um abalo enorme nas concepções originais da fotografia. Nesse período, há uma ruptura nas fronteiras temáticas e uma evolução estética que dança, entre os limites da fotografia, com a arte e a expressão. Temos também uma crescente massificação da produção jornalística e a crise nas revistas ilustradas com o advento da televisão e a migração dos investimentos publicitários. Surge um embate entre a tecnologia (televisão e multimídia) e o valor documental da fotografia, que cresce progressivamente com o desenvolvimento das tecnologias de transmissão ao vivo.

assiste-se a uma dupla progressão: os constantes aperfeiçoamentos do dispositivo fotográfico são acompanhados do declínio paulatino do valor documental das imagens. Isso em razão da dificuldade em responder às novas necessidades da sociedade atual em relação às imagens. (ROUILLÉ, 2009, p. 28)

Esse embate reduz a autoridade social do fotojornalismo em matéria de representação e figuração virtual do mundo. Também é possível constatar manipulações no fotojornalismo, como em fotorreportagens com fotografias encenadas na revista Paris Match, de junho de 1966 (SOUSA, 2000), assim como a extirpação e acréscimo de figuras políticas nas imagens da Guerra Fria, que utilizou o fotojornalismo como pujante ferramenta política e ideológica. Nessa mesma época surgem revistas como Playboy, de 1953, revistas de escândalos, de moda, decoração, arquitetura e fotografia, assim como a figura dos papara$z z i$. Esse novo tipo de imprensa constitui um dos motivos para a disseminação da fotoilustração, a utilização da teleobjetiva e dos recursos técnicos de estúdio no fotojornalismo.

A fotografia é vista, a partir dessa revolução, como transformação do real (DUBOIS, 1993), já que é considerada codificada sob os aspectos culturais, técnicos, sociológicos e estéticos. A fotografia não é mais vista como um espelho; técnicas e funções diferentes passam a ser aplicadas para evidenciar este fato. Encenações de reportagens, 
edição mais extremada das imagens (supressão de personagens políticos, por exemplo), lentes teleobjetivas, técnicas de campana (para "pegar" celebridades em momentos inesperados) são técnicas, até então, pouco ou não utilizadas, que passam a ser vigentes e aceitáveis. As funções também mudam; a fotografia não serve mais apenas para registrar e documentar grandes acontecimentos, como guerras, mas para registrar coisas como o cotidiano, a rotina das celebridades, e ensaios nus femininos (função já existente há muito tempo, mas que deixa a clandestinidade).

A partir desse momento, passa a se falar em uma verdade interior (ARBUS apud DUBOIS, 1993, p. 37). É importante compreender que, segundo Dubois (1993, p. 40, grifo do autor), "se a fotografia é considerada um registro perfeitamente realista e objetivo do mundo visível é porque lhe foram designados (desde a origem) usos sociais considerados 'realistas' e 'objetivos"'. Porém, a fotografia não é evidente para qualquer receptor, é necessária a apreensão de determinados códigos de leitura para compreender a significação das mensagens. A partir desse momento, a fotografia deixa de ser entendida como transparente, inocente e realista. Ela deixa para trás o conceito de verdade empírica para abraçar a verdade interior.

Temos agora terreno fértil para uma segunda revolução do fotojornalismo (SOUSA, 2000) surgir. Com o desenvolvimento de melhores tecnologias de captação e transmissão, cada vez mais a televisão toma o espaço da fotografia como representação da realidade. Para Sousa, a televisão reduz a autoridade do fotojornalismo como representação virtual do mundo. Sem essa responsabilidade, a fotografia tem espaço para a criatividade e para testar seus limites. Nesse mesmo tempo, a Guerra do Vietnã e o movimento hippie estão intimamente ligados. Os fotojornalistas entram nas linhas de frente das batalhas, junto com os soldados. Nunca houve uma proximidade tão grande com os horrores da guerra (Ibid., 2000). A exposição se transforma em uma invasão da privacidade, um apelo para a sensibilidade do leitor, um choque de realidades (a guerra no outro lado do mundo, o conforto do lar). As fotografias funcionam como uma denúncia contra o governo norte-americano, os fotógrafos se libertam da censura, tudo é permitido para chocar (Ibid., 2000).

Há também um crescente número de agências de fotografia sendo criadas, o que implica no aumento da rotinização da produção. A concorrência cresce vertiginosamente, o que acentua os aspectos negativos das concepções do jornalismo sensacionalista (SOUSA, 2002, p. 152). A roteirização da reportagem (DUBOIS, 1993) entra nas rotinas de produção dos fotojornalistas graças à concorrência desenfreada. Há uma mudança de postura por parte dos fotógrafos e editores. Com as extremas mudanças no mercado, a construção das fotografias se torna aceitável visando a maior lucratividade. É uma completa inversão de valores e de postura ética até então vigentes. 
A roteirização rompe, então, com um regime de verdade, o da reportagem, que durante muito tempo se apoiara nas noções de imagem-ação, de contato direto com o real, e de registro, em vez do culto ao referente e ao instantâneo. Os acontecimentos ocorrem, o fotógrafo capta-os ao vivo, sem intervir e sem modificá-los: esta era a verdade da reportagem, diante da qual a representação levanta naturalmente o problema da falsificação. De um lado, a informação seria "capturada"; do outro, "fabricada". (ROUILLÉ, 1993, p. 144)

Rouillé afirma que essa oposição é artificial, porque se baseia na concepção de que o repórter é completamente objetivo e neutro. Todas as decisões tomadas para a captura de uma fotografia, todas, são uma afirmação de um ponto de vista, são escolhas. Ainda afirma que mais importante que os conceitos de verdade e falsificação é a passagem de um regime de verdade para outro: “A reportagem encenada não é menos verdadeira do que a reportagem 'ao vivo', ela corresponde a um outro regime de verdade, a outros critérios suscetíveis de sustentar a convicção, ou a outras expectativas” (Ibid.).

Nesse período, a televisão se torna o meio de comunicação dominante e na comunicação em geral, a concorrência aumenta, acentuando os aspectos negativos das concepções do jornalismo sensacionalista (SOUSA, 2002, p. 152). Isso causa um abandono da tradicional função sociointegradora que os meios possuíam em benefício do espetáculo e da dramatização da informação. Isso é visível nas fotografias da Guerra do Vietnã, como naquelas do fotógrafo Don McCullin.

um esteta do horror, ávido de denunciar o mal, que ele afirmava distinguir claramente por trás do visor. Nessas guerras, tal como em acidentes e em ocasiões dramáticas, o fotojornalismo tende a explorar os caminhos da sensibilidade, dirigindo-se frequentemente à emoção e utilizando, amiúde, a foto-choque. (Ibid.)

Como outros aspectos relevantes desse período, podemos salientar o livre acesso dos jornalistas às zonas bélica e de conflito, como a Guerra do Vietnã, e a subsequente proibição do acesso pelos militares aos conflitos seguintes (como a Guerra do Golfo e das Malvinas) devido à repercussão das imagens capturadas; a oferta homogênea de fotografias com as agências de fotografias; o controle dos fotojornalistas fora de cenários de guerra; a entrada da fotografia nos museus e a crescente rotinização e convencionalização da fotografia. Além disso, a partir dos anos 1980, é implementado o uso generalizado do computador para reenquadrar fotos, escurecê-las ou clareá-las, e retocá-las de forma geral. Rouillé (2009, p. 144) trata desse aspecto argumentando que qualquer enquadramento é inclusão ou exclusão; que qualquer ponto de vista é 
uma tomada de posição; que qualquer registro é construção: que informar é criar o acontecimento e representá-lo.

Essa segunda revolução traz a ideia da fotografia como traço de um real (DUBOIS, 1993). Apesar de a televisão estar tomando para si o valor da fotografia como atestação do real, resiste na fotografia, segundo Dubois (Ibid., p. 26), "um sentimento de realidade incontornável do qual não conseguimos nos livrar apesar da consciência de todos os códigos que estão em jogo nela e que se combinaram para a sua elaboração". Essa revolução é um processo de transição. Nos princípios anteriores, a fotografia possuía um valor absoluto. Como espelho do real, era da ordem de semelhança (ícone para Peirce) e como transformação do real, da ordem da codificação e convenção (símbolo para Peirce). Agora a fotografia será considerada da ordem do índice, que representa a contiguidade física, o contato entre o signo e seu referente, sem a necessidade de semelhança. Isso implica que a imagem possui um valor singular ou particular, porque é determinada por seu referente e só por ele mesmo; é o traço desse real único. É importante também conceituar a noção de "isso foi", de Roland Barthes (1984, p. 114), que diz que "Chamo de 'referente fotográfico' não a coisa factualmente real a que uma imagem ou signo remete, mas a coisa necessariamente real que foi colocada diante da objetiva, na falta do que, não haveria fotografia".

Dubois (1993) afirma que antes e depois da inscrição da imagem na superfície sensível, de ambos os lados existem gestos que dependem de escolhas e decisões humanas, sendo somente o momento preciso da captura da imagem completamente fora do alcance da intervenção da mão do fotógrafo. Justamente por seu princípio de testemunha, a fotografia aponta, como em Barthes (1984), e atesta a existência do objeto, mas não o seu sentido. A foto índice nos afirma o "isso foi", mas não nos consegue dizer "isso que diz aquilo"; a fotografia retorna ao referente, mas longe do mimetismo. A fotografia se torna inseparável do seu ato fundador: sua realidade afirma a existência física do referente, porém, nada dos diz além disso. Numa revolução onde os valores deixam de ser absolutos e passam a ser absolutamente singulares e particulares, não há limites. O referente está presente e isto basta como conexão com a realidade. O resto é absolutamente relativo. Tudo é passível de criação e intervenção.

No início dos anos 90 nos deparamos com a terceira revolução no fotojornalismo (SOUSA, 2002). Ela se liga, primeiramente, à disseminação dos programas de edição de imagem e às possibilidades de manipulação e geração computacional de imagens. Pela primeira vez a atividade é questionada no âmbito de sua relação com o real. A transmissão digital imediata também abre espaço para o aumento da pressão sobre o trabalho dos jornalistas, que passam a ter menos tempo para o planejamento e execução das pautas. Surge uma nova tendência gráfica que consagra a legibilidade, permitindo as imagens de caráter meramente ilustrativo. Há também uma industrialização das rotinas de produção 
fotojornalística, centradas no imediatismo. Os estilos fotojornalísticos glamour, fotoilustração, fotoinstitucional, features e fait-divers ganham cada vez mais espaço, e finalmente, uma convergência entre a captação de imagens fixas (fotografia) e em movimento (audiovisual) pelo mesmo profissional. Segundo Rouillé (2009, p. 30) "Atualmente, o declínio das funções documentais da fotografia acompanha o fim da modernidade e da sociedade industrial, e traduz-se em uma eclosão das práticas entre os múltiplos-domínios a fotografia, a arte contemporânea e as redes digitais".

De acordo com Sousa (2002), a televisão e os meios multimídia reduziram a autoridade social do fotojornalismo em matéria de representação e figuração virtual do mundo. Sem a autoridade de representação, surge o espaço para a liberdade criativa. Todas essas inovações trazem a necessidade de readaptação. Soulages (2010) afirma que o fotojornalismo não mostra o real, mas suprime do real, o que vai contra a ideologia do veículo sobre o real. Rouillé (2009, p. 32) explica que, durante muito tempo, modernos e antimodernos se recusam a achar um meio-termo que conciliasse máquina e homem, que admita que a arte e a fotografia não são irreconciliáveis a priori: uma conciliação entre arte e fotografia. Novos modelos e convenções de produção se fazem urgentes; novas rotinas produtivas, estratégias profissionais, de processamento, seleção, edição e distribuição. O imediatismo da televisão, a internet e as redes sociais trazem a questão atual e de caráter imprescindível no fotojornalismo: é preciso questionar a natureza do fotojornalismo, seus padrões de produção, valores, e sua responsabilidade ética.

Enquadrando esse momento no que Dubois (1993) assume como fotografia como traço de um real, vemos a fotografia livre da responsabilidade de ser a forma de representação perfeita, de atestação e testemunha, ainda assim existe na imagem uma sensação de realidade da qual não conseguimos nos livrar, mesmo sabendo dos códigos e processos envolvidos. Há uma importante transição, nesta visão, da ordem de valores: anteriormente, como espelho do real, era da ordem de semelhança - (ícone para Peirce) e como transformação do real, da ordem da codificação e convenção (símbolo para Peirce), seu valor era absoluto; agora a fotografia será considerada da ordem do índice, que representa a contiguidade física, o contato entre o signo e seu referente, sem a necessidade de semelhança, ou seja, de valor singular, porque é definida somente por seu referente, um traço desse real único.

Barthes conceitua o que chama de "isso foi", que é o objeto real, físico, necessário para a obtenção da fotografia. $\mathrm{O}$ "isso foi" é importante porque mostra a volta à questão do referente, mas longe do ideal do mimetismo. Ele confirma o caráter de testemunha da fotografia porque atesta a existência do objeto. Porém, Barthes se fia cegamente nesse conceito, de forma extrema, a ponto de dizer que a mensagem é sem código. É pego na armadilha do referencialismo, tornando absoluto o princípio da "transferência da realidade". 
Pode-se relacionar os conceitos de Rouillé sobre roteirização da reportagem à ideia de traço do real. Há uma conexão física, um "isso foi”, mas ele não nos dá um significado (DUBOIS, 1993, p. 85). A fotografia é inseparável de seu ato fundador, afirmando a existência física do objeto, mas não diz nada além disso. Não porque ela é vazia e sem código, mas porque os significados são relativos, porque há potencial para criação e para interpretação que vão além da simples gênese automática. Como os valores agora são singulares, o fotojornalismo é autorizado a assumir procedimentos como o da roteirização.

Na década de 1980, a fotografia começa a, timidamente, invadir os museus de arte, e os computadores surgem, lentamente, sendo utilizados para retocar as fotografias. Retoques esses que são intervenções, procedimentos assumidos. Essas mudanças na produção estimulam o surgimento de uma nova onda, uma nova visão da imagem. Ao assumir os procedimentos técnicos que invertem a postura ética original do fotojornalismo, chegamos ao ponto atual de debate da área. As rotinas de produção do fotojornalismo chegaram a um ponto crítico na era da internet. Cada vez mais, é preciso mais velocidade, é crucial ser o primeiro a publicar a imagem na rede. O imediatismo torna as rotinas de produção cada vez mais doentias, entrando em um círculo vicioso. A velocidade se torna preferencial à qualidade. Cada vez mais as agências de notícias tornam-se o centro alimentador de imagens. Segundo Sousa (2000, p. 201), os estilos fotojornalísticos glamour, fotoilustração, fotoinstitucional, features e fait-divers ganham cada vez mais espaço, e finalmente, uma convergência entre a captação de imagens fixas (fotografia) e em movimento (audiovisual), pelo mesmo profissional.

A tecnologia das câmeras digitais e dos programas de edição de imagem são, atualmente, incomensuráveis. Por mais que já seja dominante o conhecimento de que o fotojornalismo não é objetivo, ainda há o embate ético que permeia a questão da edição das imagens. Até onde ir? Qual é o limite?

A invasão de privacidade também entra na pauta do debate. Com o acesso globalizado à internet, com a democratização das câmeras fotográficas em smartphones, não existe mais privacidade, mesmo para quem não seja uma celebridade ou pessoa pública. Há uma vigilância e mobilização de massa para a divulgação de imagens, qualquer deslize estará postado na internet. Qualquer passo em falso pode tirar uma pessoa comum do anonimato, basta um clique. Qualquer foto pode ser divulgada na internet sem os devidos créditos do autor, editada e manipulada sem o seu consentimento. A fotografia é, na sua natureza, de domínio universalmente público?

Esse é o momento de reavaliação da atividade, e do que Flusser (2002, p. 71) chama de "urgência de uma filosofia da fotografia". Flusser argumenta que qualquer definição exclui o homem enquanto fator ativo e livre. Urge para que toda e qualquer definição 
seja contestada, porque essa contestação impulsiona o pensar filosófico. Para ele, no decorrer do último século, o homem foi relegado ao setor terciário; os aparelhos (por aparelho Flusser que dizer um "brinquedo que simula um tipo de pensamento", e neste caso especificamente, a câmera fotográfica) assumindo o trabalho, o homem que "brinca com símbolos vazios; como o interesse dos homens vai se transferindo do mundo objetivo para o mundo simbólico das informações" (Ibid., p. 72). Homem e máquinas se alimentam em um círculo vicioso. Onde fica o espaço para a liberdade?

Flusser afirma que o fotógrafo é o homem que já vive dentro deste totalitarismo dos aparelhos e não obstante, se considera livre. Ele seria o protótipo do novo homem. Quatro pontos-chave são arrolados em sua teoria: o aparelho é inferior ao homem e pode ser enganado; é possível introduzir o caráter humano nos programas do aparelho; as informações produzidas por esses aparelhos podem ser desviadas pelas intenções humanas; o aparelho é desprezível. Somente os fotógrafos experimentais são conscientes da práxis da fotografia, já que conscientemente tentam obrigar o aparelho a produzir imagens informativas que não estão inseridas no seu programa. Para Flusser, a fotografia representa a possibilidade de viver de forma livre em um mundo dominado e controlado pela tecnologia.

\section{Considerações finais}

De um espelho, uma representação perfeita do real, a fotografia passa por um questionamento filosófico de sua ontologia, e a ser vista como uma linguagem, que depende de códigos de leitura de muitos níveis diferentes para a sua interpretação. Todas essas mudanças, reflexo da nova visão da fotografia como transformação do real, influenciam as técnicas, produção e estética da imagem.

Apesar de seu curto período de existência, a fotografia se mostrou mutante, capaz de evoluir junto ao pensamento do homem, impulsionada por grandes eventos, mudanças de valores, formas do homem ver a si mesmo e de se posicionar no mundo. Passando de um "espelho do real" para um "traço do real", a fotografia e o fotojornalismo se encontram em um novo momento de revolução, com as novas possibilidades atribuídas à tecnologia e às rotinas de produção condizentes com a internet e a comunicação imediatista.

Flusser urge por uma nova filosofia da fotografia que busca a liberdade da práxis fotográfica. É preciso lembrar, porém, que o autor trata da fotografia, e não do fotojornalismo. De todo modo, ambos passaram a ser vistos como procedimentos assumidos, gestos que requerem escolhas e afirmação de pontos de vista. No entanto, por mais que busquemos formas de "brincar com o aparelho", não podemos esquecer as questões éticas que permeiam a prática fotojornalística. 


\section{Referências}

BARTHES, R. A câmara clara. Rio de Janeiro: Nova Fronteira, 1984.

DUBOIS, P. O ato fotográfico e outros ensaios. Campinas: Papirus, 1993.

FLUSSER, V. Filosofia da caixa preta: ensaios para uma futura filosofia da fotografia. Rio de Janeiro: Relume Dumará, 2002.

LOUZADA, S. Fotografia, modernidade e imprensa carioca: as primeiras décadas do século XX. In: ENCONTRO DE HISTÓRIA ANPUH, 13., 2008, Rio de Janeiro. Anais eletrônicos... Rio de Janeiro: [s.n.], 2008. Disponível em: <https://bit.ly/2IonmKJ>. Acesso em: 4 set. 2011.

MACHADO, A. A ilusão especular. São Paulo: Brasiliense, 1984.

MAUAD, A. M. O olho da história: fotojornalismo e história contemporânea. Revista ComCiência, Campinas, 10 mar. 2004. Disponível em: <https://bit.ly/2rLJ5VZ>. Acesso em: 4 set. 2011.

ROUILLÉ, A. A fotografia: entre documento e arte contemporânea. São Paulo: Senac, 2009.

SOULAGES, F. Estética da fotografia: perda e permanência. São Paulo: Senac, 2010.

SOUSA. J. P. Uma história crítica do fotojornalismo ocidental. Florianópolis: Letras Contemporâneas, 2000. Fotojornalismo: uma introdução à história, às técnicas e à linguagem da fotografia na imprensa. Florianópolis: Letras Contemporâneas, 2002. 